\title{
職場における健康管理の発展と課題
}

\author{
荘司榮徳(下葉産業保啸推進センター)
}

管見となるここをお許しいただき、硉康管理の側面 から今世紀における産業衛生の足跡を辿ってみたい。

このお卡百年の間に、職場における健康管理の体 制は次第に整備され、価く人々の健康状態が好転して いることに異論は無いよ思うが、以下今世紀を終戦を 境に二分して論ずることとする。

\section{20 世蚁前半の棷覾（1901～1945）}

明治の開国以降の努力により、槽維産業を中心よす る工業化に成功したわが国は、第 1 次世界大戦を契機 に重化学工業化も進み、工業生産は1900年を 100 しす ると、1944年には2.144 に達した。

この間の労做者の健康状况には問題が多かった。

1900 瞕工数 34 万、うち紡績業22万（8割が女工）

粘核が黄延し、ペストが度々流行していた。

1913 「女工と結核」(石原) 㷌鄉死亡の 7 割が結核 1920～計器工場、鍍金師の水銀中毒（鲤沼） 蓄電池工場での鈆中毒（鲤沼）

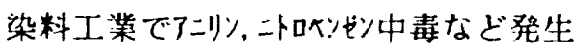

1923 隅田川架橋工事で潜函病発生

1925 「女工哀史」(細井)

1928 京都レーヨン工場で二硫化炭素中毒が多発

こうした状况八の対态をみると、

1901 八幡製鉄所が完成し同時に病院を発足

1919 全国21,042工場中診療所等設置は235

で、診療は開業医が、職業病は大学が扱っていた。

1916 工場法施行

1921 含敷学㗢科学研究所設立 (暉唆)

1929 産業衛生協議会例立（暉找理事長）

などの動きもあり、

1929 工場危害予防及衙生規則公布

1938 同規則改正（500人以上の匹場に工場医）

1938 化学峨維工業保健衛生調查会発，足

こうして工場医が選任され、年 1 回の健康診断が開 始された。組織的健康管理の始まりである。

以後、戦時色が濃くなり、㕍業衛生は停滞の時期に 入ったが、結核は国民病とまでいわれ、

1940 東京鉄道管理局保健課が讱回班を編成

以後每年 8 力月間の集畞検診を続けた。(千葉ら)

1941 工場健保が結核集団检診 7 力年計画開始

結核対象の健康管理の萌芽となった。

\section{20 世蚁後半の概観(1946～1997）}

\section{(1) 臨床診療之健康管理}

典型的な職業病、職業性膀胱痹の硉康管理、特に化 成品「業界のヘソシシ\%，2-ナフナル下ミ対策に注目したい。 1948 化成品工業協会が発足

1960 Heuper博士、Villiams博士を招聘、講演会開催 1961 I.C. I社から介心们法導入、普及指導（石律） 自主的健康管理の方法確立と推進

1970 退䣹者に健康管理手帳の交付開始（本省文書）

1972 安衛則に上る健康管理手悵硉診項目の通達

1975 「尿細胞誩のアトラス」完成（石津）

員かれた健康管理の成果は、受診群の余命が非受診 群の3倍という成績に現れている。

さらに、専門医による綿密な追跡検查の挒があり、

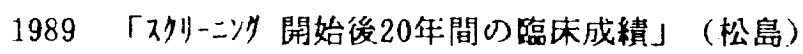

ヘシツツ 作業従事者90名を対象に、1967年から 双リ二 州を開始し、尿細胞診陽性者等に皘極的な諸検查上治 㞠老行った結果、18症列を発見し、

(1) 尿細胞診に上る膀胱癌の診断㴆は $92 \%$

(2) 膀腃癌、层管癌による亘接的死亡はなく

(3) 5 年生存 $80 \% 、 10$ 年生存 $56 \% 、 15 \sim 20$ 年生存 $37 \%$ の)戊精を得ている。

新物質、未知の健康影響が㦛念されるだけに、職業 性疾病の 2 次予防のために、優机た検查手法の確立、 適切な制度、そし、て侮床専門医との緊密な連携に配慮 しなけ机ばならないことを苚感する。

\section{(2) 研究機関と健康管理}

化棅工業界のC S 2 八の取の組みにも注目したい。 戦中から問題であった急性、要急性のC S 2 障害は 環境改善により好転したが、C $\mathrm{S}_{2}$ 僈性障害が次第に 明らかになり、業界は硉康管理を強化した。

1949 化学嵊維工業学衔衛生研究会の再開 1946～CS: による腷血管障害、動脈硬化の報告読く 1964～全工場一斉硉診（久保田、原島、椐原ら）

10 年間の調査で $\mathrm{CS}_{2}$ 由来の動脈硬化所見は無く、 生活面の促進因子が強くないためと理解された。 1968 $\mathrm{CS}_{2}$ と虚血性心疾患の疫学調查報告 (4 例) 1991〜 慢性障害に関する10年間のコホート調查開始

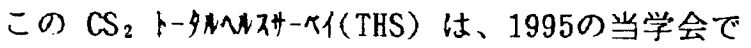
間報告されている。（桜井、公濑ほか） 
健康障害に関する最新の情報を把握し、矿究機関の 協力を得て先進的な健康調查を進めるこ上は、硉康管 理の基としてて今後とも重視す心゙きここし考える。

\section{（3）環境管理と健康管理}

中世から鉱夫の踺康を菏人で来たじん肺の健康管理 については他の演者に委妃、悑足的に述へたい。

1948〜 珪肺健診を 3 年間実施(学㗢省)

46.000名を健㟝し、有所見 $12 \%$

1952 鉣山医学研究会が発足

1953 同研究会が自主的調盗を実施

20 鉱山 21,992 名、珪肺 $17 \%$ 、广ち $28.5 \%$ 結核合併。 以後、関係者による精力的な調查研究が続けられ、職 場における環境改善も鋭意推進されたが、最近次の上 うな注目す心゙き発素(沼野)がある。

1992 95 粉じん緗場の換気に関する調查（沼野ら）

1984 93 日测協の精度管理㟟本調查（舆、沼野）

1979 95 じん肺娭診結果調查報告（労働省）

の結果から、じん肺有病率と環境の第且管理区分の間 に明らかな相関関係が認められたこいう。

慢性の眏業性疾患に対する工学的対策の効果の確認 は、長期かつ広範囲にわたり容易ではない。今後の健 康管理の成果確認のために参考にすべきと考える。

\section{（4）作䒠管理·環境管理と健康管理}

戦後、鉄銅業でも産紫衛生の活動志発展した。 1951 日本鉄銿連盟に労铺衛生専門委員会を設置

機関誌「鉄銅労衝衛生」が刑行された。 1951 65 1 ～ 3 次の合理化、技術導人で設備一新 1966〜 各社の新鋭侮海製鉄所続々上操業開始

こうして労徽態梯や作業環境は様変わりし，たが、高 熱重筋労㗢の負荷を適正な筙用にとどめることは、趾 康管理上重要な課題であった。

発汗量の測定も行われ（小川、林）、T GE指数（ 齐藤ら)の利用もまったが、私详は川铁温熱指数(K H I J を考案、作業環境管理と作業時間管理の㖤面に 活用し、硉康の確保に資した。

黒球温度、風速乞R．M.R. か. ら要処理熱量を捉え、水 蒸気玨と風速から放散熱量を捉え、この比から商温環 境を評価し、他方体内残留熱量が一定限度以下に抑元 られるよう作業時間を管理することにより負倚を速正 範用に収的る手法である。

これは、作業者標準時間の設定や温熱環境の適正化 にもつながり、1970年、3 組 3 交替制から 4 組3 交替 制に移行する際にも適正要員算定の主要な一条件乞な った。

\section{(5) 一般健康診断の吐展}

鉄鋼業の咨病较計をみると、1960年から10年間に、 欠勤日数率は 16.87 名ら 10.21 (千分率）に40\%施少 し、病類別では呼吸器系結核の83.6\%娍、呼吸器系の その他疾患の $40.3 \%$ 消化器系疾患の $26.8 \%$ 減が目 立去、結核対策の成果が明らかである。

労衝省の統計でも1956年 (3.5\%) から順調に低下し て1975年には $0.4 \%$ よなっており、休業走要しない療 養者も著しく減少している。

鉄銅業32事業場に対する1969年.調查に上机は、耤核 以外の健康管理対象疾患は、循㻴器疾患30事業場、胃 晹疾患16事業場、榶尿病10事業場乞なっており、次第 に成人病に対象を搪げていたことが分かる。

高齢化とともにこの䫅向が一般に拡がり、1989年の 規則改正（健診項目追加）に及ぶが、その後の有所見 率の推移は周知のと扣りで、38\%に達している。

改正一般定期健診が浸透したよみら机る1996年健診 後の措置充実の法改正があり、脳血管疾患、虚血性心 疾患の予防に近づこうこしている。

\section{(6)これからの健康管理について}

以上概観するこ、こ孙らの健康管理には、従来的 課题、即与職業性疾病の予防、感染症予防、成人病予 防、硉康づくり等に次の課題が加わると思われる。

i，職業姞慢性障害の予防

ii．新物質等による賤業性㷋病の回避

iii. 生活留慣病の 1 次予防

iv. 作䉾関連疾患の予防

v 、メンタルヘルスを含む健康づくり

vi，産業衛生全般の小規模事業場八の浸透

そしてこれら課題に対処するため望まれる要件は、

(1)職業性疾病要因の慢性影笪に関する研究

(2)新物質等の導入に関する産業衛生上の手続き確立

(3)生活習慣病予防のための健康教育、ニュアル作成

(4)ライフスタイルの調查法と評価方法

(5)作業関連疾患予防のための基礎疾患の管理手法

(6)実用的なストレス評価方法、ストレス対策の開発

(7)小規模事業場支援ネットワークの充実

なよ゙であるうと考える。

幸い、産業保健センターの整備は進み、作業関連突 患予防のマニュアルは発刊され、産業ストレスのモテ ル・要因・ライフスタイル評価などの諸研究、大規模 な循環器疾患のリスク低下のための介入研究なども進 んでおり、その成果が待たれる。職場では㻴境管理・ 作業管理しの連携、医撩機関・研究機関との交流を図 りつつ健康管理にこの成果を活用したいものでおる。 